\title{
A reconnaissance study on the magmatic Cu-Ni-PGE sulphide potential of the Tete Complex, Mozambique
}

\author{
W.D. Maier \\ Centre for Research on Magmatic Ore Deposits, Department of Geology, \\ University of Pretoria, Pretoria 0002, South Africa, \\ e-mail: wdmaier@scientia.up.ac.za \\ Sarah-Jane Barnes \\ Sciences de la Terre, Université du Québec, Chicoutimi, G7H 2B1, Canada \\ e-mail: sjbarnes@uqac.uquebec.ca \\ L.D. Ashwal \\ Department of Geology, University of the Witwatersrand, Johannesburg, South Africa, \\ e-mail: 1da@cosmos.wits.ac.za \\ C. $\mathrm{Li}$ \\ Department of Geological Sciences, University of Indiana, Bloomington, in 47405, USA \\ e-mail: cli@indiana.edu
}

\begin{abstract}
The Tete Complex of Mozambique is a composite mafic-ultramafic intrusion that consists largely of pyroxenites and gabbros, with lesser amounts of coarse-grained troctolitic and anorthositic rocks reminiscent of massif-type anorthosites. The Complex thus may have potential to host reef-type PGE ores and/or massive $\mathrm{Ni}-\mathrm{Cu}$ sulphides analogous to those found in the gabbro-troctolite hosted Voisey's Bay deposits. We analysed 8 isotopically and mineralogically well-characterized samples of anorthosite, leucotroctolite, clinopyroxenite, gabbro, olivine melagabbro, dolerite, and a pegmatitic orthopyroxenite for major and trace elements, including PGE. The samples show little evidence for significant crustal contamination and are mostly undepleted in PGE relative to $\mathrm{Cu}$, and to a lesser degree, Ni. If the samples are representative of the intrusion, this may indicate that the Complex has limited potential to host economic $\mathrm{Ni}-\mathrm{Cu}$ sulphide ores. The potential for reef-type PGE ores remains less clear, in view of the occurrence of such ores in seemingly uncontaminated intrusions elsewhere (e.g. the Great Dyke).
\end{abstract}

\section{Introduction}

The Tete Complex of Mozambique has been grouped with some 30 other massif-type anorthosites in Gondwana (Ashwal, 1993). Until relatively recently, anorthosite-troctolite-gabbro suites were thought to have a low potential for magmatic $\mathrm{Ni}-\mathrm{Cu}$ ores, which may explain why the Tete Complex has remained poorly explored. The discovery of the Voisey's Bay deposits (Ryan et al., 1995) has changed this outlook and anorthosite-troctolite-gabbro suites are now explored for $\mathrm{Ni}-\mathrm{Cu}$ ores worldwide.

More recently, Evans et al. (1999) have proposed that the Complex consists largely of mafic-ultramafic rocks (gabbros, olivine gabbros, pyroxenites,), with only a relatively small proportion (some 5\%) of coarse-grained anorthositic and leucotroctolitic rocks. This raises the possibility that the Complex may also host reef-type PGE mineralization analogous to the Bushveld Complex or the Great Dyke. In order to generate some preliminary exploration guidelines for the Complex, we have determined major element oxides, trace elements including platinum-group elements (PGE), as well as $\mathrm{Ni}$ contents of olivines in a relatively small, but wellcharacterized sample suite.

\section{Regional and local geology}

The Tete Complex measures some $800 \mathrm{~km}^{2}$ and is located in western Mozambique (Figure 1), at the intersection of the Zambesi (predominantly 795 to $880 \mathrm{Ma}$ ) and Mozambique (predominantly 1000 to $1100 \mathrm{Ma}$ ) orogenic belts (Evans et al., 1999). A major crustal lineament, the Sanangoe Shear Zone, bounds the northern margin of the Complex, but it remains unclear as to whether this controlled the intrusion of the magmas. The country rocks to the Complex comprise a diverse assemblage of shelf-type supracrustal rocks, including marble, calcsilicate gneiss, quartzite, amphibolite, banded ironstone, phyllites, pelitic schists, conglomerates and greywackes, as well as mafic-felsic intrusives. Inclusions of some of the immediate country rocks in the magmas have been interpreted as evidence for an intrusive relationship of the Complex with its hostrocks, but Evans et al. (1999) argued that abundant dolerite dykes within the Complex are largely absent in the country rocks, thereby pointing to a tectonic emplacement.

Evans et al. (1999) estimated that the most common rock type within the Complex is olivine gabbro, with subordinate thin layers of clinopyroxenite. Leucotroctolite and anorthosite amounts to less than $5 \%$ of the 


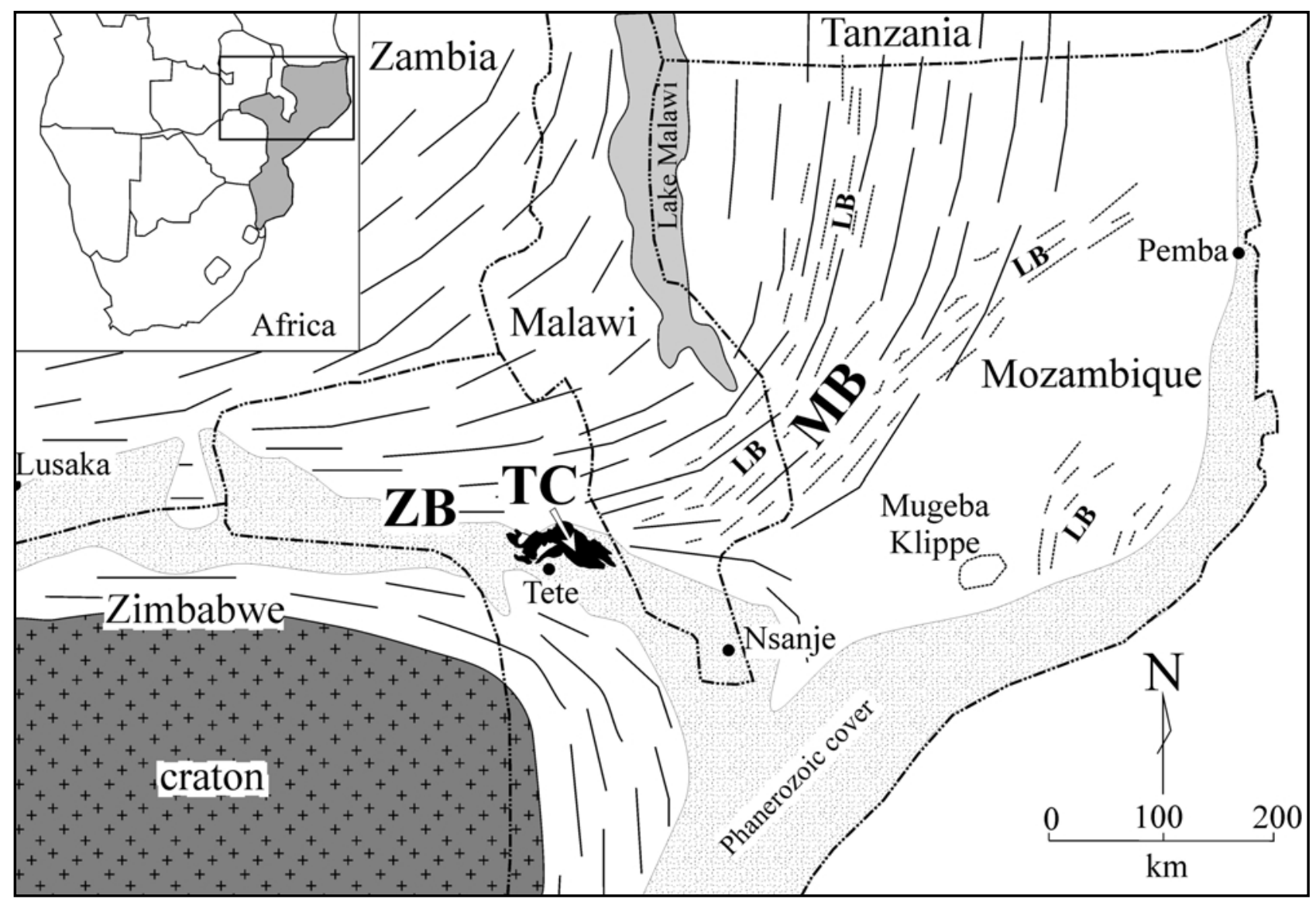

Figure 1. Simplified geological map, showing the tectonic framework of northern Mozambique and indicating location of the Tete Complex. From Evans et al. (1999).

outcrop and is concentrated in the $30 \mathrm{~km}^{2}$ Nyangoma area. Magnetite rubble associated with the latter indicates the possible presence of titanomagnetite layers or bodies. Based partly on textural evidence, the anorthosites appear to be equivalent of massif-type anorthosites, and thus Evans et al. (1999) suggest that the Tete Complex may be akin to intrusions with features transitional between massif-type anorthosites and layered intrusions such as the Duluth and Michikamau intrusions.

\section{Previous analytical work on the Tete Complex and the present sample suite}

The most comprehensive published dataset on the Tete Complex is that by Evans et al. (1999). Information published prior to this is largely descriptive (e.g. Barr and Brown, 1987), with the exception of some Sm/Nd isotope data (Barr at al., 1984). The results of Evans et al. (1999) indicate that the different rock types of the Complex span a wide range of compositions. Forsterite contents of olivine range between 83 to $59, \mathrm{Mg} \#$ $(=\mathrm{Mg} /[\mathrm{Mg}+\mathrm{Fe}])$ of clinopyroxene range from 86 to 60 , and An contents of plagioclase from 77 to 39. Evans et al. (1999) proposed that the various rocks were derived from a common parental magma, as indicated by similar values of $\epsilon_{\mathrm{Nd}}$. Accordingly the clinopyroxenites and anorthosites might be cumulates from evolved magmas, which fractionated from relatively primitive gabbroic magma represented by the olivine melagabbro and the dolerites.

Evans et al. (1999) further noted that the clinopyroxenes in the pyroxenites have extremely high $\mathrm{Al}_{2} \mathrm{O}_{3}$ contents (up to 9 weight \%), analogous to high-Al megacrysts in massif-type anorthosites that are commonly interpreted as high-P crystallization products (e.g. Emslie, 1975). However, the Tete pyroxenes do not contain exsolved plagioclase. Together with the distinct zoning of olivines and plagioclase (Evans et al., 1999) this has been explained by relatively fast ascent of the magmas combined with high cooling rates at shallow crustal levels.

The Nd isotopic data of Evans et al. (1999) indicate a crystallization age for the Complex of $1025 \pm 79 \mathrm{Ma}$, and derivation of the magmas from depleted mantle $\left(\epsilon_{\mathrm{Nd}}+3.4\right.$ to +4.5$)$. The $\mathrm{Nd}$ isotopic data of Barr et al. (1984) and the Sr isotopic data of Evans et al. (1999; $\mathrm{Sr}_{\mathrm{i}}$ 0.702758 to 0.702878 ) are largely in agreement with this interpretation. Notably, dolerites within the Complex appear to have higher $\epsilon_{\mathrm{Nd}}$ values than the gabbroic and anorthositic rocks, which led Evans et al. (1999) to suggest that the cumulates may have been slightly more contaminated with Neoproterozoic crust than the dolerites. 

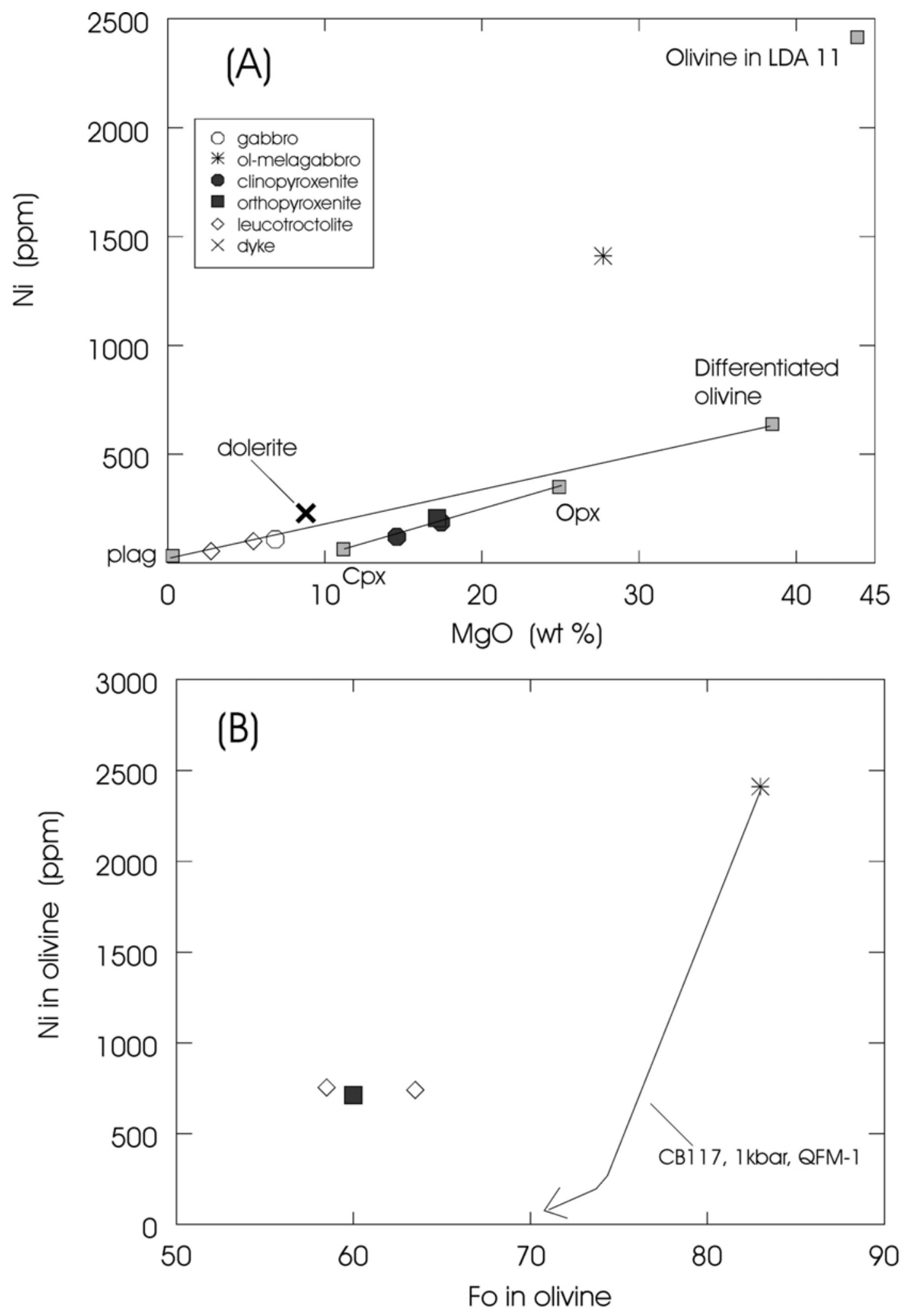

Figure 2.. (A) Binary variation diagram of whole rock Ni versus $\mathrm{MgO}$. (B) Ni versus Fo contents of olivine. See text for explanation. 


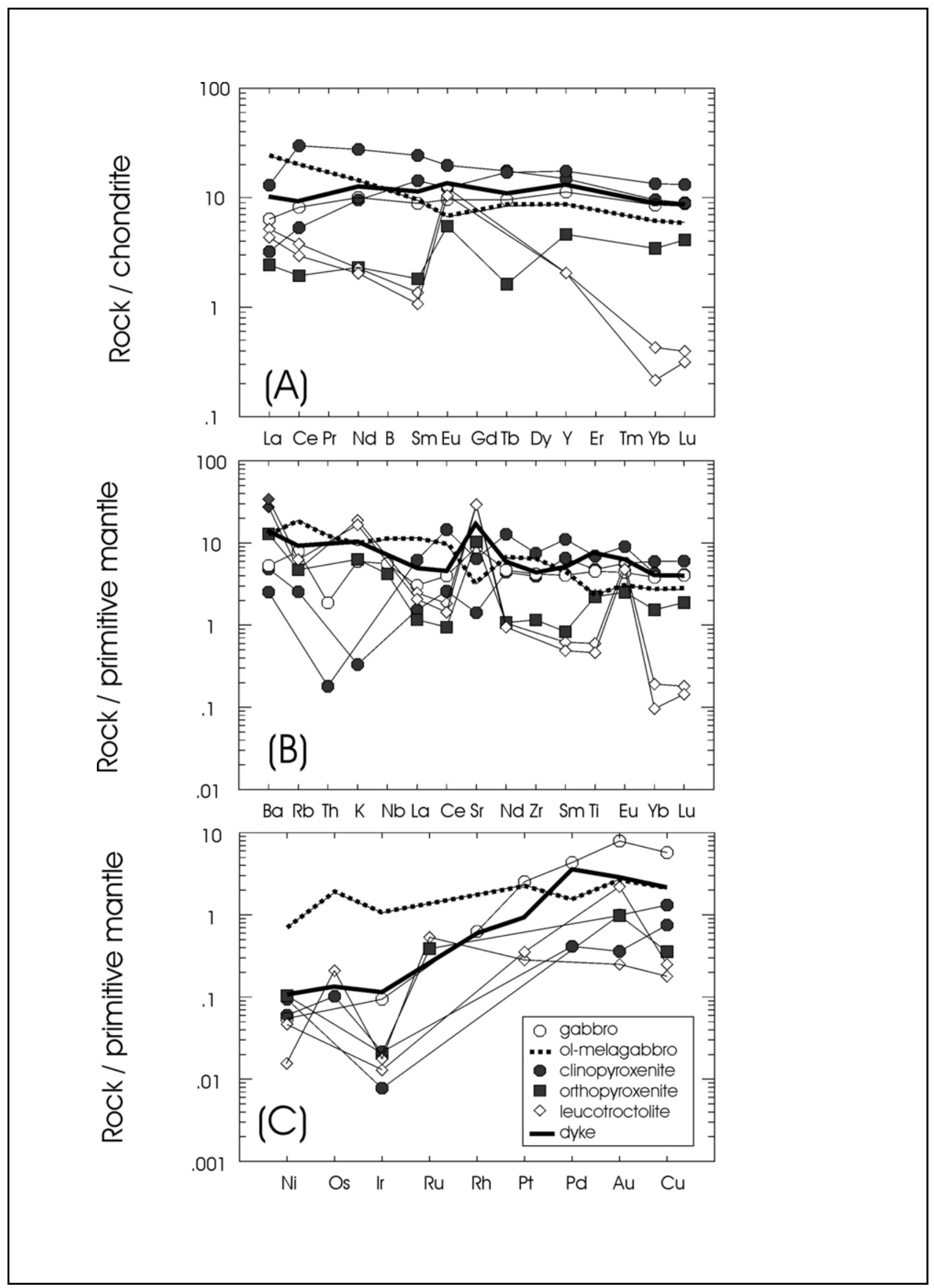

Figure 3: (A) Chondrite-normalized REE patterns. Normalization factors from Taylor and McLennan (1985). (B) Mantle-normalized trace element patterns for analysed samples. Normalization factors from Sun and McDonough (1989). (C) Primitive mantle-normalized PGE patterns. Normalization factors from Barnes and Maier (1999). 
Table 1. Compositional data for rocks from the Tete Complex

\begin{tabular}{|c|c|c|c|c|c|c|c|c|}
\hline $\begin{array}{l}\text { Sample Name } \\
\text { Rocktype }\end{array}$ & $\begin{array}{c}\text { LDA } 11 \\
\text { Ol-melagb }\end{array}$ & $\begin{array}{l}\text { LDA } 19 \\
\text { Gabbro }\end{array}$ & $\begin{array}{c}\text { LDA } 3 \\
\text { Clinopx }\end{array}$ & $\begin{array}{l}\text { LDA 5b } \\
\text { Clinopx }\end{array}$ & $\begin{array}{c}\text { D } 467 \\
\text { Leucotroct }\end{array}$ & $\begin{array}{c}\text { TRDAN } \\
\text { Leucotroct }\end{array}$ & $\begin{array}{c}\text { MASS } \\
\text { Orthopx }\end{array}$ & $\begin{array}{c}\text { CB } 117 \\
\text { Dolerite }\end{array}$ \\
\hline $\mathrm{SiO}_{2}(\mathrm{wt} \%)$ & 41.66 & 47.86 & 45.57 & 48.11 & 51.20 & 48.90 & 47.71 & 46.42 \\
\hline $\mathrm{TiO}_{2}$ & 0.51 & 0.98 & 1.50 & 1.03 & 0.13 & 0.10 & 0.48 & 1.65 \\
\hline $\mathrm{Al}_{2} \mathrm{O}_{3}$ & 7.01 & 17.05 & 7.91 & 5.70 & 26.67 & 23.30 & 9.18 & 16.39 \\
\hline $\mathrm{Fe}_{2} \mathrm{O}_{3}$ & 13.58 & 12.06 & 14.26 & 16.91 & 3.95 & 7.43 & 20.33 & 12.48 \\
\hline $\mathrm{MnO}$ & 0.19 & 0.18 & 0.21 & 0.32 & 0.05 & 0.10 & 0.26 & 0.19 \\
\hline $\mathrm{MgO}$ & 27.71 & 6.85 & 17.41 & 14.59 & 2.77 & 5.47 & 17.14 & 8.80 \\
\hline $\mathrm{CaO}$ & 5.11 & 12.68 & 12.32 & 13.31 & 9.98 & 8.94 & 3.98 & 11.02 \\
\hline $\mathrm{Na}_{2} \mathrm{O}$ & 0.44 & 2.04 & 0.58 & 0.53 & 4.37 & 3.59 & 1.02 & 2.32 \\
\hline $\mathrm{K}_{2} \mathrm{O}$ & 0.28 & 0.18 & 0.00 & 0.01 & 0.57 & 0.50 & 0.19 & 0.31 \\
\hline $\mathrm{P}_{2} \mathrm{O}_{5}$ & 0.05 & 0.07 & 0.08 & 0.00 & 0.01 & 0.01 & 0.03 & 0.16 \\
\hline LOI & 2.48 & 0.17 & -0.06 & -0.63 & 0.02 & 1.22 & -0.73 & 0.10 \\
\hline Total & 99.02 & 100.12 & 99.78 & 99.88 & 99.72 & 99.56 & 99.59 & 99.84 \\
\hline $\mathrm{Rb}$ (ppm) & 12 & 5 & $<2$ & 2 & 3 & 4 & 3 & 6 \\
\hline $\mathrm{Ba}$ & 87 & 37 & 18 & 34 & 192 & 239 & 90 & 98 \\
\hline $\mathrm{Sr}$ & 67 & 188 & 136 & 30 & 623 & 617 & 218 & 365 \\
\hline $\mathrm{Cr}$ & 4469 & 143 & 1408 & 300 & 14 & 9 & 159 & 121 \\
\hline $\mathrm{Ni}$ & 1362 & 85 & 171 & 137 & 32 & 85 & 189 & 177 \\
\hline $\mathrm{Cu}$ & 59 & 161 & 37 & 21 & 5 & 7 & 10 & 62 \\
\hline $\mathrm{Co}$ & 108 & 46 & 79 & 72 & 21 & 44 & 106 & 50 \\
\hline $\mathrm{Se}$ & 0.44 & 0.62 & 0.74 & 0.78 & $<0.23$ & $<0.35$ & $<0.44$ & 0.81 \\
\hline Sc & 21 & 42 & 43 & 76 & 2 & 2 & 27 & 37 \\
\hline V & 129 & 261 & 194 & 374 & 16 & 11 & 130 & 269 \\
\hline $\mathrm{Zn}$ & 61 & 31 & 71 & 39 & 46 & 119 & 110 & 61 \\
\hline As & 0.00 & 0.14 & 0.24 & 0.71 & $<0.11$ & $<0.06$ & $<0.06$ & 0.26 \\
\hline $\mathrm{Sb}$ & 0.02 & $<0.04$ & 0.03 & 0.02 & $<0.01$ & $<0.01$ & $<0.02$ & 0.04 \\
\hline $\mathrm{Ta}$ & 0.39 & 0.14 & 0.04 & $<0.04$ & $<0.02$ & $<0.02$ & $<0.03$ & 0.09 \\
\hline $\mathrm{Nb}$ & 8 & 4 & $<2$ & $<2$ & $<2$ & $<2$ & 3 & $<2$ \\
\hline $\mathrm{Hf}$ & 1.79 & 1.20 & 2.41 & 1.57 & 0.07 & 0.00 & 0.52 & 1.46 \\
\hline $\mathrm{Zr}$ & 72 & 47 & 84 & 44 & $<10$ & $<10$ & 13 & 50 \\
\hline $\mathrm{Y}$ & 17 & 22 & 29 & 34 & 4 & 4 & 9 & 26 \\
\hline Th & 1.07 & 0.16 & 0.02 & $<0.08$ & $<0.04$ & $<0.04$ & $<0.04$ & $<0.06$ \\
\hline $\mathrm{La}$ & 7.91 & 2.10 & 4.27 & 1.05 & 1.70 & 1.42 & 0.80 & 3.37 \\
\hline $\mathrm{Ce}$ & 17.28 & 7.07 & 25.76 & 4.59 & 3.28 & 2.54 & 1.68 & 8.01 \\
\hline $\mathrm{Nd}$ & 9.01 & 6.32 & 17.33 & 5.99 & 1.43 & 1.28 & 1.45 & 8.00 \\
\hline $\mathrm{Sm}$ & 1.92 & 1.80 & 4.92 & 2.91 & 0.28 & 0.22 & 0.37 & 2.32 \\
\hline $\mathrm{Eu}$ & 0.52 & 0.74 & 1.52 & 0.95 & 0.95 & 0.80 & 0.42 & 1.04 \\
\hline $\mathrm{Tb}$ & 0.42 & 0.48 & 0.87 & 0.85 & 0.00 & 0.00 & 0.08 & 0.54 \\
\hline Ho & 0.62 & 0.74 & 0.80 & 1.12 & 0.08 & 0.00 & 0.24 & 0.72 \\
\hline $\mathrm{Yb}$ & 1.35 & 1.88 & 2.10 & 2.95 & 0.09 & 0.05 & 0.76 & 2.00 \\
\hline $\mathrm{Lu}$ & 0.20 & 0.30 & 0.31 & 0.45 & 0.01 & 0.01 & 0.14 & 0.29 \\
\hline Os (ppb) & 6.393 & $<0.63$ & $<0.31$ & 0.347 & 0.710 & $<0.35$ & $<0.58$ & 0.462 \\
\hline Ir & 3.608 & 0.320 & 0.026 & 0.073 & 0.060 & 0.044 & 0.070 & 0.385 \\
\hline $\mathrm{Ru}$ & $<5$ & $<2$ & $<2$ & $<4$ & 3 & $<2$ & 2 & $<4$ \\
\hline $\mathrm{Rh}$ & $<0.93$ & 0.60 & $<0.44$ & $<0.55$ & $<0.54$ & $<0.41$ & $<0.55$ & 0.57 \\
\hline Pt & 16 & 18 & $<3$ & $<1$ & 2 & 2 & $<1$ & 6 \\
\hline $\mathrm{Pd}$ & 6 & 17 & $<3$ & 2 & $<9$ & $<5$ & $<4$ & 14 \\
\hline $\mathrm{Au}$ & 2.70 & 7.83 & 0.98 & 0.36 & 0.25 & 2.18 & 0.97 & 2.89 \\
\hline $\operatorname{Re}$ & 0.40 & 0.72 & $<0.26$ & $<0.12$ & $<0.23$ & $<0.29$ & $<0.34$ & 0.48 \\
\hline $\mathrm{S}(\mathrm{ppm})$ & 350 & 90 & $<50$ & $<50$ & $<50$ & $<50$ & $<50$ & 107 \\
\hline An plag & 72.8 & 76.6 & 42.6 & 42.6 & 51.7 & 53.9 & nd & nd \\
\hline $\mathrm{Mg} \#$ opx & nd & nd & 73.4 & 58.2 & 61.1 & 69.7 & 63.8 & nd \\
\hline Fo Olivine & 83.8 & 73.4 & nd & nd & 59.3 & 63.8 & 60.9 & nd \\
\hline $\mathrm{Ni}$ in Olivine & 2411 & nd & nd & nd & 754 & 741 & 713 & nd \\
\hline $\mathrm{Sr}^{\mathrm{i}}$ & nd & nd & nd & nd & 0.70276 & 0.70284 & nd & nd \\
\hline$\epsilon_{\mathrm{Nd}}$ & nd & nd & nd & nd & 4.0 & 3.5 & nd & nd \\
\hline $\mathrm{Mg \#} \mathrm{wr}$ & 80.16 & 52.94 & 70.74 & 63.08 & 58.14 & 59.32 & 62.54 & 58.27 \\
\hline
\end{tabular}

Notes: Ol-melagb = olivine-melagabbro; clinopx = clinopyroxenite; leucotroct $=$ leucotroctolite;

Orthopx = olivine orthopyroxenite

nd $=$ not determined 

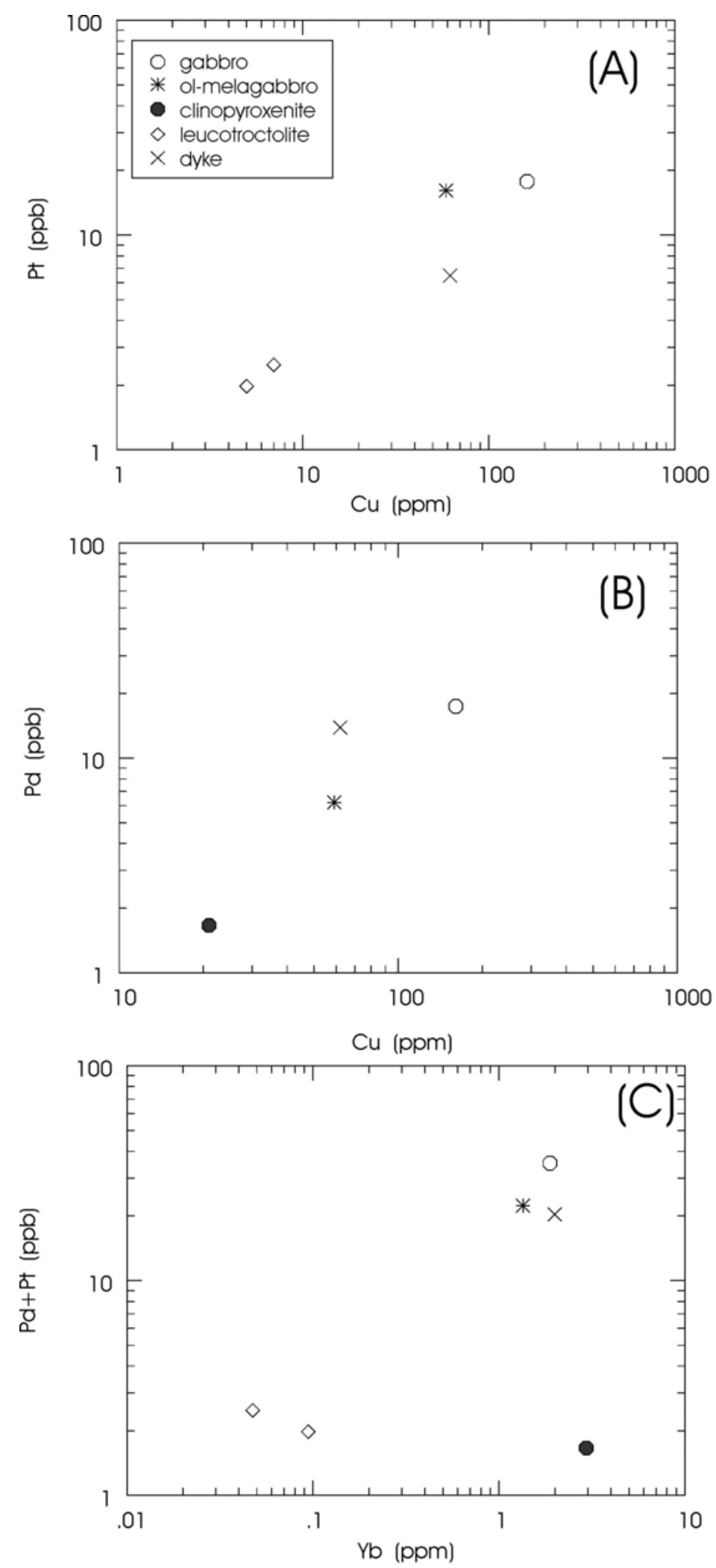

Figure 4. Binary variation diagrams of (A) Pt vs Cu, (B) Pd vs Cu, and (C) Pt+Pd vs Yb. See text for explanations. 


\section{Petrography}

Eight samples of relatively unaltered olivine gabbro, gabbro, clinopyroxenite, olivine orthopyroxenite, leucotroctolite, as well as one dolerite dyke were studied petrographically.

(i) Leucotroctolites: In sample TRDAN large, irregular olivines (variably serpentinized), with lesser orthopyroxene up to 2 to $5 \mathrm{~mm}$ across are surrounded by lath-shaped (up to $5 \mathrm{~cm}$ across), blocky, equant, and granoblastic plagioclase. Some orthopyroxene forms symplectic intergrowths with $\mathrm{Fe}-\mathrm{Ti}$ oxides \pm green spinel. Plagioclase is mostly unaltered (save for minor sericite and epidote), but contains abundant, randomlyoriented opaque needles and dust, which are responsible for overall black colouration of hand specimens. Sample D467 shows intergrowth of irregular to blocky plagioclase crystals (to 1 to $2 \mathrm{~cm}$ across), mainly in an interlocking, adcumulus texture. Small amounts of irregular, interstitial olivine and orthoyroxene occur as grains up to $5 \mathrm{~mm}$ across. In some cases, thin (up to $0.2 \mathrm{~mm}$ ) rims of orthopyroxene surround irregular olivines. Minor, irregular Fe-Ti oxides up to $1 \mathrm{~mm}$ across are commonly associated with latemagmatic (?) biotite and zones of calcic myrmekite (where in contact with plagioclase). Plagioclase contains similar opaque needles and dust as in sample TRDAN.

(ii) Olivine Gabbro (LDA-19): Irregular primocrysts of plagioclase ( 3 to $5 \mathrm{~mm}$ across), olivine ( 1 to $2 \mathrm{~mm}$ ) and clinopyroxene ( 1 to $2 \mathrm{~mm}$ ) in a finer-grained $(0.2$ to $0.5 \mathrm{~mm}$ ) groundmass of randomly-oriented plagioclase laths, irregular clinopyroxene and $\mathrm{Fe}-\mathrm{Ti}$ oxides. Plagioclase shows moderate compositional zoning, both in primocrysts and in groundmass. Late-magmatic and/or secondary alteration is minimal, and is restricted to very minor red-brown biotite rims on some $\mathrm{Fe}-\mathrm{Ti}$ oxides.

(iii) Olivine Melagabbro (LDA-11): Equant to irregular olivine $(0.2$ to $2 \mathrm{~mm})$, partially enclosed by poikilitic clinopyroxene up to $4 \mathrm{~mm}$ across, and irregular, intercumulus, moderately zoned plagioclase grains up to $6 \mathrm{~mm}$ across. Fe-Ti oxides occur as small, equant grains (0.1 to $0.2 \mathrm{~mm}$ ) scattered throughout the rock. Many olivines are largely serpentinized, although abundant primary grains are preserved. Other secondary minerals include red-brown biotite and minor sericite (after plagioclase).

(iv) Pegmatitic olivine orthopyroxenite (MASS): Intergrowths of large (up to several $\mathrm{cm}$ ), finely-exsolved orthopyroxene, and irregular (to 5 to $6 \mathrm{~mm}$ ) olivine, with very minor intercumulus, zoned plagioclase (irregular areas up to $2 \mathrm{~mm}$ across), and small, equant, irregular FeTi oxides $(0.2$ to $0.5 \mathrm{~mm})$. Late-magmatic or secondary red-brown biotite occurs in association with Fe-Ti oxides, especially in the interstitial, plagioclase-rich areas. Very minor clinopyroxene occurs as thin $(0.2 \mathrm{~mm})$ rims between olivine and plagioclase. Secondary alteration is minimal.

(v) Clinopyroxenites (LDA 5a and LDA 3): Clinopyroxene (80 to 90 volume \%) occurs as large (up to $2 \mathrm{~cm}$ ), subhedral, grains containing broad orthopyroxene exsolution lamellae, blebs, and distinct peripheral grains, as well as minor, brown and black, Fe$\mathrm{Ti}$ oxide lamellae, prisms, and blebs. Additional Fe-Ti oxides occur as discrete prismatic and anhedral crystals interstitial to the clinopyroxenes. In sample LDA 3, the oxides may be associated with minor green spinel and apatite. Minor plagioclase ( $<1$ volume \%) occurs as an interstitial phase in both samples. The texture of the rocks (in particular LDA 3a) is distinctly granular, showing tripple point junctions.

(vi) Dolerite (CB-117): Randomly-oriented, highly zoned plagioclase laths ( 0.5 to $2 \mathrm{~mm}$ across) in a groundmass of intergrown olivine, clinopyroxene, $\mathrm{Fe}-\mathrm{Ti}$ oxides and red-brown biotite. Very minor green spinel is associated with some Fe-Ti oxides. Alteration is minimal, and is restricted to replacement of some clinopyroxene by very fine-grained carbonates.

\section{Analytical methods}

The samples were milled in a C-steel mill at the University of Pretoria (UP) and analysed for major elements as well as Rb, Sr, V, Zn, Nb, Zr, and Y by XRF at UP. All other elements were determined at the University of Quebec at Chicoutimi: S by combustion iodometric procedure using a LECO titrator, $\mathrm{Cu}$ by atomic absorption spectrometry (AA), and the other trace elements by instrumental neutron activation analysis (INAA) using the method of Bedard and Barnes (1990). The PGE,Au and Re were determined by INAA after pre-concentration of the metals in a Ni-sulphide bead from $50 \mathrm{~g}$ samples. All analytical data are shown in Table 1. Further details on these samples, including mineral compositions and isotopic data can be found in Evans et al. (1999) and Evans (1998).

\section{Results}

The samples span a relatively wide range of major element compositions (Table 1). Most of the cumulates may be compositionally compared to rocks from the Upper Zone of the Bushveld Complex, whereas the olivine melagabbro has whole rock $\mathrm{Mg \#}$ and $\mathrm{Cr}$ contents, as well as Fo similar to those from the Critical Zone of the Bushveld Complex (von Gruenewaldt, 1973; Cameron, 1980). In contrast, most massif-type anorthosites with which the Tete Complex has been grouped before are compositionally more homogeneous (Ashwal, 1993). Thus, the major element data confirm the observations of Evans et al. (1999) that the bulk of the Complex is more akin to a layered mafic-ultramafic intrusion than a massif-type anorthosite.

An important question with regard to the mineralization potential and the petrogenesis of the Complex is whether the analysed dolerite represents the composition of the parental magma to the cumulates. We first consider some major- and compatible trace element data (Figure 2). Olivine in the olivine melagabbro has a composition similar to that modelled to be in equilibrium with the dolerite (using 
MELTS: Fo83, 2400ppm Ni; Figure 2a), consistent with crystallization of the melagabbro from the dolerite magma. The gabbro (LDA-19) crystallized from a more differentiated magma than that represented by the dolerite; it has olivine with $\mathrm{FO}_{73}$, and MELTS modelling would indicate that the parental magma could have been differentiated dolerite after some $40 \%$ fractionation of olivine $(0.65 \%)$, olivine+plag $(\sim 35 \%)$, and finally olivine+plag+cpx $(\sim 5 \%)$. The leucotroctolites (D467, TRDAN) can be explained as mixtures between plagioclase (approximately 85 to 95 volume \%) and relatively evolved olivine ( 5 to 15 volume \%) having about 600 ppm Ni (Figure 2a). According to MELTS such olivine would crystallize from the differentiated dolerite after about $30 \%$ fractionation of olivine and plagioclase. However, the olivines in the leucotroctolites are more Fe rich (Fo59-64, Table 1) than the modelled olivine, which should have a composition of about Fo77 (see also Figure 2b). We suggest that the olivines in the leucotroctolites represent phenocrysts that equilibrated with Fe-rich intercumulus melt, having little effect on $\mathrm{Ni}$ contents of the olivines due to the high $\mathrm{D}$ values of $\mathrm{Ni}$ with regard to olivine (around 12.5 for a magma of the composition of the differentiated dolerite, Li et al., 2001). The clinopyroxenites have low Mg\# between 63 and 71 . Ni contents of the pyroxenes are not known, but based on the whole rock values of between 120 and 190ppm Ni (Table 1), the Ni contents of the pyroxenes should fall between 150 and 200ppm, in accord with Figure 2a. Thus the clinopyroxenites crystallized from magma more differentiated than the dolerite, but the available major element data are inconclusive as to whether they are of a similar lineage as the dolerite.

The dolerite has flat REE patterns with a slight positive Eu anomaly (Figure 3a). The pattern is broadly similar to that of the gabbro, at slightly higher concentrations, and is in accord with derivation of the magma from a depleted mantle source. With the exception of $\mathrm{Eu}$, the leucotroctolites have much lower REE contents and patterns that are controlled by cumulus plagioclase. The clinopyroxenites have variable patterns, but their REE contents are mostly higher than those of the dolerite. The patterns may be governed by variable proportions of cumulus clinopyroxene $(\mathrm{La} / \mathrm{Lu}<1)$ and differentiated trapped melt $(\mathrm{La} / \mathrm{Lu}>1)$. The pegmatitic orthopyroxenite has flat patterns with a distinct positive Eu anomaly, indicative of orthopyroxene and cumulus plagioclase control. Notably, the olivine melagabbro has more fractionated patterns than most of the other rocks, and a negative $\mathrm{Eu}$ anomaly indicative of plagioclase fractionation.

A more complete range of incompatible trace elements are plotted normalized to primitive mantle in Figure $3 \mathrm{~b}$. In addition to positive Eu anomalies, the data show positive $\mathrm{Sr}$, as well as $\mathrm{Ba}$ and $\mathrm{K}$ anomalies for the leucotroctolites, the pegmatitic orthopyroxenite and the dolerite, confirming the presence of cumulus plagioclase. The olivine melagabbro has relatively high concentrations in all highly incompatible trace elements. With the exception of the olivine melagabbro, none of the samples has negative $\mathrm{Nb}$ or $\mathrm{Ti}$ anomalies that would indicate the presence of an upper crustal component.

Ytrium and $\mathrm{Hf}$ are highly incompatible trace elements that occur at levels above detection limit in most of the analysed rocks. Y/Hf ratios are between 17 and 18 for the dolerite, the gabbro, the orthopyroxenite and one of the clinopyroxenites. The leucotroctolites have unreliable $\mathrm{Y}$ and Hf levels close to the analytical detection limit. The second clinopyroxenite has a value of 12 , and the olivine melagabbro has the lowest value of the samples analysed (Y/Hf 9).

In summary, the available major- and lithophile trace element data suggest that the dolerite, the gabbro, and the pyroxenites could be of a common magmatic lineage. The data for the leucotroctolites are inconclusive. The olivine melagabbro appears to be enriched in highly incompatible trace elements, indicating the presence of a relatively larger crustal component.

The spidergrams of the chalcophile metals (Figure 3c) show relatively smooth patterns for the gabbros and the dolerite, i.e. the PGE are not markedly enriched or depleted relative to $\mathrm{Cu}$ and $\mathrm{Ni}$. The leucotroctolites, clinopyroxenites, and the olivine orthopyroxenite are markedly depleted in Ir relative to $\mathrm{Ni}(\mathrm{Ni} / \mathrm{Irm}>1)$, but this pattern is partially caused by silicate-hosted Ni. It is perhaps more diagnostic that the PPGE (Rh,Pt,Pd) are undepleted relative to $\mathrm{Cu}$ in the leucotroctolites and the olivine orthopyroxenite, but slightly depleted in the clinopyroxenites. These trends indicate insignificant sulphide segregation from the parental magmas to the analysed rocks, a proposal that is in accord with the low S content of the dolerite (Table 1) indicating a high degree of $S$ undersaturation. The IPGE depletion of the more evolved rocks may be ascribed to minor fractionation of PGM such as laurite, which may crystallize directly from basaltic magma as indicated by recent experimental data (Brenan and Andrews, 2001).

Pt and Pd show a well-defined positive correlation with $\mathrm{Cu}$ (Figures $4 \mathrm{a}$ to b). Further, Pt and Pd correlate positively with incompatible trace elements (Figure 4c). Together with the low S contents of the dolerite and most of the cumulates, this suggests control of the chalcophile elements by trapped silicate melt rather than sulphides.

The olivine melagabbro also has undepleted PGE contents relative to $\mathrm{Cu}$ and $\mathrm{Ni}$, and the concentrations of the IPGE are markedly higher than in the other rocks. The metal pattern of the sample resembles that of a picrite or komatiite, but is rather unusual for a gabbroic cumulate. The patterns may be explained by the presence of IPGE-rich PGM such as laurite, or a small mss component. A small sulphide component may also be indicated by markedly higher S contents compared to the remainder of the rocks. The distinct metal pattern and $\mathrm{S}$ content of this sample possibly support the notion 
raised earlier that the olivine melagabbro is not directly related to the other samples investigated.

\section{The sulphide potential of the Tete Complex}

Our incompatible trace element data (Figures $3 \mathrm{a}$ and b) are in broad agreement with the proposal of Evans et al. (1999), based largely on $\mathrm{Nd}$ isotopes, that the Tete Complex crystallized from magmas that were derived from depleted mantle with relatively little crustal component.

The studies of Wendlandt (1982) and Mavrogenes and O'Neill (1999) have shown that the S solubility of mantle magmas increases with falling pressure. Therefore, to induce significant supersaturation of sulphide, addition of external (crustal) $\mathrm{S}$ or contamination with siliceous partial melt is probably required. The apparent absence of a significant crustal signature in the Tete Complex could thus be a negative factor in the massive sulphide potential of the Complex. In comparison, mafic dykes associated with the Nain anorthosite suite (Scoates and Mitchell, 2000) have a much more distinct crustal signature in terms of both spider patterns and $\mathrm{Nd}$ isotopes.

In most of the analysed Tete rocks, the PPGE and Au are undepleted relative to $\mathrm{Cu}$ (Figure 3c), which suggests that their parental magmas have not experienced significant sulphide segregation. Comparison of the chalcophile metal contents to lithophile incompatible trace elements (Figure 4c) further indicates that the metals are controlled by trapped intercumulus melt rather than cumulus sulphides. In contrast to the other cumulates, the clinopyroxenites have crystallized from slightly PGEdepleted magmas that may have reached sulphide saturation during advanced differentiation. The combined data imply that those portions of the Tete Complex represented by our samples have a limited potential to host massive $\mathrm{Cu}-\mathrm{Ni}$ sulphide mineralization.

The potential of the Complex to host reef-type PGE deposits remains less clear. On the one hand, the PGE mineralized Great Dyke shows little apparent crustal signature (Hamilton, 1977) and apart from the reefs most of the silicate rocks are PGE-poor, i.e. compositional characteristics similar to the samples studied here. The Bushveld Complex, on the other hand, has a distinct crustal signature and virtually all silicate cumulates are either PGE-depleted relative to $\mathrm{Cu}$ and $\mathrm{Ni}$ (i.e. above the reefs) or contain cumulus sulphides (i.e. below the reefs) (Maier and Barnes, 1999), a pattern that indicates sulphide saturation throughout most of the intrusion's crystallization history.

\section{Acknowledgements}

The present research has been supported by a Research Development Grant of the University of Pretoria (to WDM) and an NSERC grant (to SJB). We thank Grant Cawthorn and Chris Hatton for their constructive reviews.

\section{References}

Ashwal, L.D. (1993). Anorthosites: Berlin, Springer Verlag, 422 p. Barnes, S.-J. and Maier, W.D. (1999). The fractionation of $\mathrm{Ni}, \mathrm{Cu}$ and the noble metals in silicate and sulphide liquids, In: R. R. Keays, C. M. Lesher, P. C. Lightfoot, P.C. and C. E. G. Farrow (Editors), Dynamic processes in magmatic ore deposits and their application to mineral exploration: Geological Association of Canada, Short Course Notes, 13, 69-106.

Barr, M.W.C. and Brown, M.A. (1987). Precambrian gabbro-anorthosite complexes, Tete Province, Mozambique: Geological Journal, 22, 139-159. Barr, M.W.C., Downing, K.N., Harding, A.E. and Loughlin, W.P. (1984). Regional correlation near the junction of the Zambesi and Mozambique Belts, east-central Africa: Unpublished open-file report, Hunting Geology and Geophysics Ltd., Inst. Nacional de Geol., Maputo, Mocambique, 77 pp. Bedard, L.P., and Barnes, S.-J. (1990). Instrumental neutron activation analysis by collecting only one spectrum: Results for international geochemical reference samples: Geostandards Newsletter, 14, 479-484.

Brenan, J.M. and Andrews, D. (2001). High-temperature stability of laurite and Ru-Os-Ir alloy and their role in PGE fractionation in mafic magmas: Canadian Mineralogist, 39, 341-360.

Cameron, E.N. (1980). Evolution of the lower Critical Zone, central sector, and its chromite deposits: Economic Geology, 75, 845-871.

Emslie, R.F. (1975). High pressure pyroxene megacrysts from anorthositic rocks and their bearing on the genesis of the parental magmas. Geological Society of America, Abstracts with Programme, 7, 752-753.

Evans, R.J. (1998). Mafic, ultramafic and anorthositic rocks of the Tete Complex, Mozambique: petrology, age and significance., Unpublished M.Sc. Thesis, Rand Afrikaans University, Johannesburg, South Africa, $127 \mathrm{p}$.

Evans, R.J., Ashwal, L.D. and Hamilton, M.A. (1999). Mafic, ultramafic and anorthositic rocks of the Tete Complex, Mozambique: petrology, age and significance: South African Journal of Geology, 102, 153-166.

Hamilton, J., 1977, Strontium isotope and trace element studies on the Great Dyke and Bushveld mafic phase and their relation to early Proterozoic magma genesis in southern Africa. Journal of Petrology, 18, 24-52.

Li, C., Maier, W.D., and de Waal., S.A. (2001). Magmatic Ni-Cu versus PGE deposits: Contrasting genetic controls and exploration implications. South African Journal of Geology, 104, 355-362.

Maier, W.D. and Barnes, S.-J. (1999). Platinum-group elements in silicate rocks of the Lower, Critical and Main Zones at Union Section, Western Bushveld Complex. Journal of Petrology, 40, 1647-1671.

Mavrogenes, J.A. and O'Neill, H.St.-C. (1999). The relative effects of pressure, temperature, and oxygen fugacity on the solubility of sulfide in mafic magmas. Geochimica et Cosmochimica Acta, 63, 1173-1180.

Ryan, B., Wardle, R.J., Gower, C.F. and Nunn, G.A.G. (1995). Nickel-copper sulphide mineralization in Labrador: the Voisey's Bay discovery and its exploration implications. Geological Survey, Department of Natural Resources, Government of Newfoundland and Labrador, Current Research Report, 95, 177-204.

Scoates, J.S. and Mitchell, J.N. (2000). The evolution of troctolitic and high Al basaltic magmas in Proterozoic anorthosite plutonic suites and implicatiosn for the Voisey's Bay massive Ni-Cu sulfide deposit. Economic Geology, 95, 677-701.

Sun, S.-S. and McDonough, W.F. (1989). Chemical and isotopic systematics of ocean basalts: implications for mantle composition and processes, In: A.D. Saunders and M. J. Norry, M.J. (Editors), Magmatism in the ocean basins. Geological Society, Oxford, Special Publication, 42, 313-345.

Taylor, S.R. and McLennan, S.M. (1985). The Continental crust: its composition and evolution: Blackwell Scientific, Oxford, U.K., 312 p.

Von Gruenewaldt, G. (1973). The Main and Upper Zones of the Bushveld Complex in the Roossenekal area, eastern Transvaal: Transactions of the Geological Society of South Africa, 76, 207-227.

Wendlandt, R.F., 1982, Sulfide saturation of basalt and andesite melts at high pressures and temperatures: American Mineralogist, 67, 877-885.

Editorial handling: J. M. Barton Jr. 
